\title{
Growth and calcification in the cephalopod Sepia officinalis under elevated seawater $\mathrm{pCO}_{2}$
}

\author{
Magdalena A. Gutowska ${ }^{1, *}$, Hans O. Pörtner ${ }^{1}$, Frank Melzner ${ }^{2}$ \\ ${ }^{1}$ Alfred-Wegener-Institute for Polar and Marine Research, 27570 Bremerhaven, Germany \\ ${ }^{2}$ Leibniz Institute of Marine Sciences, IFM-GEOMAR, 24105 Kiel, Germany
}

\begin{abstract}
Ocean acidification and associated changes in seawater carbonate chemistry negatively influence calcification processes and depress metabolism in many calcifying marine invertebrates. We present data on the cephalopod mollusc Sepia officinalis, an invertebrate that is capable of not only maintaining calcification, but also growth rates and metabolism when exposed to elevated partial pressures of carbon dioxide $\left(\mathrm{pCO}_{2}\right)$. During a 6 wk period, juvenile $S$. officinalis maintained calcification under $\sim 4000$ and $\sim 6000 \mathrm{ppm} \mathrm{CO}_{2}$, and grew at the same rate with the same gross growth efficiency as did control animals. They gained approximately $4 \%$ body mass daily and increased the mass of their calcified cuttlebone by over $500 \%$. We conclude that active cephalopods possess a certain level of pre-adaptation to long-term increments in carbon dioxide levels. Our general understanding of the mechanistic processes that limit calcification must improve before we can begin to predict what effects future ocean acidification will have on calcifying marine invertebrates.
\end{abstract}

KEY WORDS: Ocean acidification - Calcification - Metabolism - Growth · Marine invertebrate · Cephalopod $\cdot$ Sepia officinalis

\section{INTRODUCTION}

Anthropogenic carbon dioxide $\left(\mathrm{CO}_{2}\right)$ emissions are acidifying the world's oceans. While current ocean $\mathrm{pH}$ values are already more than 0.1 units below those of pre-industrial times, further increases in atmospheric $\mathrm{CO}_{2}$ concentrations to values of 1500 to $2000 \mathrm{ppm}$ could result in a drop of ocean $\mathrm{pH}$ of up to 0.8 units within the next $300 \mathrm{yr}$ (Caldeira \& Wickett 2003). Together with declining $\mathrm{pH}$ values, ocean carbonate ion $\left(\mathrm{CO}_{3}{ }^{2-}\right)$ concentrations will decrease, which in turn will lead to a reduction of calcium carbonate saturation $(\Omega)$ in seawater (Zeebe \& Wolf-Gladrow 2001). As many marine organisms form shells or skeletons from calcium carbonate minerals (primarily aragonite or calcite), considerable attention has been devoted to studying calcification processes in response to seawater acidification. Surface ocean waters are currently supersaturated with respect to both calcite and aragonite. However, recent measurements and models predict that surface seawater calcium carbonate satura- tion states are decreasing globally (Feely et al. 2004). By the year 2050 it is predicted that high latitude regions will become undersaturated $(\Omega<1)$ with respect to aragonite $\left(\Omega_{\text {arag }}\right)$ as a consequence of ocean acidification (Orr et al. 2005).

Most marine invertebrates respond negatively to elevated $\mathrm{CO}_{2}$ concentrations. Many cnidarians, molluscs and echinoderms display reduced rates of calcification (Fabry et al. 2008). Interestingly, some of these organisms display strong linear relationships of calcification rate with the saturation of calcium carbonate $(\Omega)$ (Fig. 1). The changes in calcification recorded over a $2 \mathrm{yr}$ period in the Biosphere 2 mesocosm (Langdon et al. 2000; data replotted from their Table 4 in our Fig. 1) illustrate the high sensitivity of reef building communities to calcium carbonate undersaturation. Bivalve molluscs also react sensitively to decreasing $\mathrm{pH}$ and $\Omega_{\text {arag. The work of Gazeau et al. (2007) shows that net }}$ calcification in the mussel Mytilus edulis decreases linearly with increasing $\mathrm{pCO}_{2}$, and ceases when $\mathrm{pCO}_{2}$ is above 1800 ppm (data replotted from their Table 1 in 


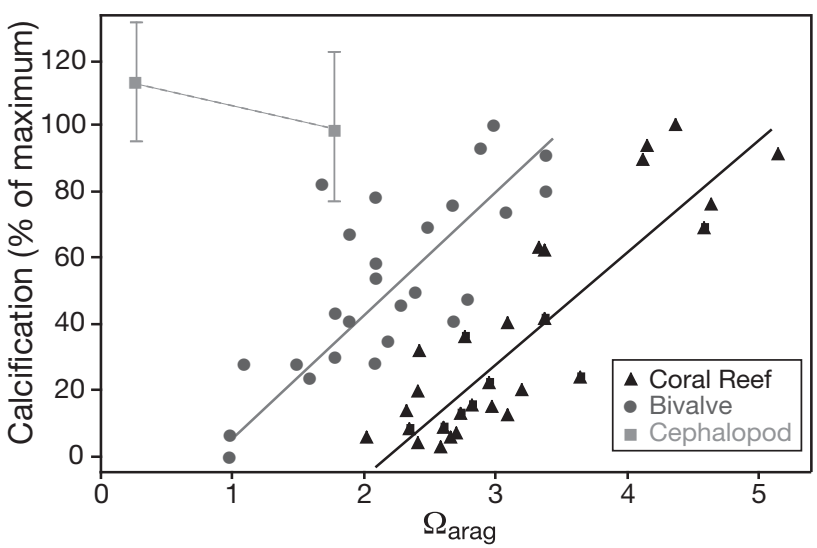

Fig. 1. The dependence of calcification on $\mathrm{CO}_{2}$-dependent seawater calcium carbonate saturation $\left(\Omega_{\text {arag }}\right)$ in marine invertebrates. Long-term coral reef data set recorded in the Biosphere 2 mesocosm (Langdon et al. 2000, data replotted from their Table 4), acute changes in Mytilus edulis (bivalve) calcification (Gazeau et al. 2007, data replotted from their Table 1), Sepia officinalis (cephalopod) calcification measured over 6 wk in this study (data are mean $\pm S D, n=20$ ). The highest calcification rates in the respective data sets were set at a value of $100 \%$

our Fig. 1). While the latter might be explained by external shell dissolution when $\Omega_{\text {arag }}<1$, decreasing calcification at $\Omega_{\text {arag }}>1$ may indicate that significant physicochemical control exists over calcification in mussels.

Marine invertebrates whose calcification processes are disturbed by elevated $\mathrm{CO}_{2}$ are also characterised by comparatively low metabolic rates and activity levels. These factors may increase a marine organisms' sensitivity to ocean acidification, as suggested by Seibel \& Walsh (2003). In response to this possibility, the present study explores the calcification and growth capacity of an active mollusc (cephalopod) with a high metabolic rate, the, European cuttlefish Sepia officinalis, under acidified conditions. Cuttlefish possess an internal aragonite shell ('cuttlebone', see Fig. 3) that serves as a structural support and, with the help of ion transport mechanisms, as a buoyancy control device (Denton \& Gilpin-Brown 1961a). Interestingly, we find that S. officinalis does not reduce its growth or calcification rate when exposed to $\sim 6000 \mathrm{ppm} \mathrm{CO}_{2}$ for a period of $6 \mathrm{wk}$.

\section{MATERIALS AND METHODS}

Experimental animals. Sepia officinalis egg clusters were collected in the Bay of Seine, Normandy, France, in May 2006 and 2007. Cuttlefish were hatched and raised at the Alfred-Wegener-Institute, Bremerhaven, Germany, in a closed recirculating system $\left(20 \mathrm{~m}^{3}\right.$ total volume, protein skimmer, nitrification filter, UV disinfection unit (Sander), salinity 32 to 34 , temperature (mean $\pm \mathrm{SD}) 15 \pm 0.1^{\circ} \mathrm{C}, \mathrm{pH} 7.9$ to 8.2 , constant $12 \mathrm{~h}$ dark:12 h light cycle). Water quality parameters were monitored weekly and concentrations of ammonia and nitrite were kept below 0.2 and $50 \mathrm{mg} \mathrm{l}^{-1}$, respectively. The cuttlefish were initially fed a daily diet consisting of live mysids Neomysis integer and progressively transitioned to feed exclusively on frozen brown shrimp Crangon crangon.

Growth trials of Sepia officinalis under elevated $\mathbf{p} \mathbf{C O}_{2}$ conditions. For the 2 growth trials, each group of 20 Sepia officinalis ind. was maintained in shallow PVC basins $(20 \times 40 \times 60 \mathrm{~cm})$. Basins drained into reservoir tanks where the seawater was pumped through a nitrifying biofilter (Eheim Pro 2) and past a 12 W UV sterilizer before being recirculated into the holding tanks. The total seawater volume of each system was approximately 3001 . Water values were maintained at $<0.2 \mathrm{mg} \mathrm{l}^{-1}$ ammonium and $<40 \mathrm{mg} \mathrm{l}^{-1}$ nitrite. Holding and reservoir tanks were continuously bubbled with the appropriate gas mixture supplied by an MKS gas controller (MKS, model GSV-19). Specific seawater conditions for the various incubations are given in Table 1. The $\mathrm{pH}$ was measured with a WTW 340i meter and SenTix81 electrode calibrated daily with National Bureau of Standards (NBS) buffers. Total dissolved inorganic carbon $\left(\mathrm{C}_{\mathrm{T}}\right)$ was measured using a gas chromatographic method modified from Lenfant \& Aucutt (1966) and Pörtner et al. (1990). Seawater carbonate chemistry parameters were calculated from $\mathrm{C}_{\mathrm{T}}$ and $\mathrm{pH}_{\mathrm{NBS}}$ with the software CO2SYS (Lewis \& Wallace 1998) using the dissociation constants of Mehrbach et al. (1973) as refitted by Dickson \& Millero (1987).

Throughout the duration of the growth trials, cuttlefish were fed ad libitum with live brown shrimp. The wet mass of shrimp consumed daily by each group was

Table 1. Seawater physiochemical conditions during 6 wk growth trials. NBS: National Bureau of Standards; $\mathrm{C}_{\mathrm{T}}$ : total dissolved inorganic carbon; $\mathrm{pCO}_{2}$ : partial pressures of $\mathrm{CO}_{2}$. Values (except aragonite saturation state, $\Omega_{\text {arag }}$ ) are mean $\pm \mathrm{SD}$

\begin{tabular}{|c|c|c|c|c|c|c|}
\hline $\begin{array}{l}\text { Incubation } \\
\text { group }\end{array}$ & $\begin{array}{c}\text { Temperature } \\
\left(\mathrm{C}^{\circ}\right)\end{array}$ & Salinity & $\mathrm{pH}_{\mathrm{NBS}}$ & $\begin{array}{c}\mathrm{C}_{\mathrm{T}} \\
\left.(\mu \mathrm{mol} \mathrm{kg})^{-1}\right)\end{array}$ & $\begin{array}{l}\mathrm{pCO}_{2} \\
(\mathrm{ppm})\end{array}$ & $\Omega_{\text {arag }}$ \\
\hline Control & $16.32 \pm 0.12$ & $32.8 \pm 0.5$ & $7.94 \pm 0.06$ & $2047 \pm 68$ & $705 \pm 101$ & 1.47 \\
\hline $\mathrm{CO}_{2} \sim 4000 \mathrm{ppm}$ & $16.37 \pm 0.12$ & $32.9 \pm 0.4$ & $7.23 \pm 0.04$ & $2451 \pm 54$ & $4271 \pm 373$ & 0.34 \\
\hline Control & $17.45 \pm 0.16$ & $31.4 \pm 0.4$ & $8.01 \pm 0.04$ & $2104 \pm 56$ & $628 \pm 60$ & 1.78 \\
\hline $\mathrm{CO}_{2} \sim 6000 \mathrm{ppm}$ & $17.43 \pm 0.15$ & $32.3 \pm 0.6$ & $7.10 \pm 0.03$ & $2583 \pm 43$ & $6068 \pm 389$ & 0.27 \\
\hline
\end{tabular}


recorded. Cuttlefish wet masses and mantle lengths were determined weekly over a period of $6 \mathrm{wk}$. Slopes of the exponential growth curves were used to determine the daily increase in percent body mass. Gross growth efficiency (percent conversion of ingested shrimp into biomass) was calculated for each group on a weekly basis by dividing the weekly increase in animal wet mass (g) by the mass of the food consumed by that group over the same time interval (Forsythe et al. 2002).

Cuttlebone dry mass and calcium carbonate $\left(\mathrm{CaCO}_{3}\right)$ content were determined upon termination of the experiment. The organic matrix contributed only 5 to $8 \%$ of total cuttlebone dry mass in the size range of sampled individuals (data not shown), the remainder of the mass being $\mathrm{CaCO}_{3}$ (aragonite). We determined $\mathrm{CaCO}_{3}$ content by back-calculating from the dry mass of the remaining organic matrix after dissolution of the cuttlebone $\mathrm{CaCO}_{3}$ fraction with $4 \mathrm{M} \mathrm{HCl}$ following Birchall \& Thomas (1983). All samples were weighed on a precision balance (ME235S, Sartorius).

Determination of standard metabolic rate under hypercapnia. Standard metabolic rates (SMR) were determined using intermittent closed respirometry. Oxygen consumption rates (3 to 4 runs of approximately 20 min each) were obtained between 08:00 and 20:00 $\mathrm{h}$ to avoid peak night activity periods of the cuttlefish (Denton \& Gilpin-Brown 1961b). Briefly, cuttlefish (mean $\pm \mathrm{SD} ; 10.4 \pm 4.3 \mathrm{~g}, \mathrm{n}=6$ ) were fasted for $24 \mathrm{~h}$ and then incubated in cylindrical perspex chambers $(3 \times 25 \mathrm{~cm})$ for a period of $3 \mathrm{~d}$ during which time they were acutely exposed to hypercapnic conditions. The chambers were perfused with seawater using an Ismatec peristaltic pump (ISM 404B) and gas-tight Tygon tubing (T4406-23). Applied flow rates (100 $\left.\mathrm{ml} \mathrm{min}^{-1}\right)$ ensured chamber oxygen partial pressures of approximately 18 to $20 \mathrm{kPa}$ between measurements. Seawater from the growth trial reservoirs was pumped through a UV sterilization unit and then used to perfuse the respiration chambers (see Table 1 for seawater values under control and hypercapnic conditions). Temperature was maintained at (mean $\pm \mathrm{SD}$ ) $16 \pm 0.2^{\circ} \mathrm{C}$ by placing the 4 replicate chambers in a water bath fitted with a thermostat. Oxygen partial pressures were measured using a fiber optic oxygen sensing system (Oxy-4
Micro, PreSens) and needle-type optodes, incorporated into the closed loop. Data were recorded using software supplied by the manufacturer, and oxygen consumption rates were calculated from linear declines in chamber oxygen partial pressure.

Statistical analyses. Results were analyzed using GraphPad Prism 4. Unpaired $t$-tests were carried out to assess the significance of differences between incubation groups at $p<0.05$. A linear regression analysis was used to determine whether oxygen consumption rates varied with exposure time. All values are expressed as means $\pm \mathrm{SD}$.

\section{RESULTS}

No differences in soft-tissue growth performance were measured between cuttlefish incubated at $\sim 4000$ and $\sim 6000 \mathrm{ppm} \mathrm{CO}_{2}$ and controls (Table 2). Final average body mass for the cuttlefish incubated at $\sim 4000 \mathrm{ppm}$ $\mathrm{CO}_{2}$ equaled $11.16 \pm 1.40 \mathrm{~g}$ compared with $11.63 \pm$ $1.39 \mathrm{~g}$ for the control group. In those incubated at $\sim 6000 \mathrm{ppm} \mathrm{CO}_{2}$ the corresponding mass was $23.06 \pm$ $4.15 \mathrm{~g}$ compared with $24.15 \pm 5.25 \mathrm{~g}$ in the controls. All 4 of the experimental groups grew at high rates typical of juvenile cephalopods (Forsythe et al. 1994, Melzner et al. 2005), increasing body mass exponentially at a rate of approximately $4 \% \mathrm{~d}^{-1}$. There were no significant differences between the exponential curves used to calculate daily growth (Fig. 2). Gross growth efficiencies (GGE), calculated from weekly means, were also similar between the 4 incubation groups; the values ranged between $36.6 \pm 6.2 \%$ and $39.5 \pm 4.5 \%$, and there were no significant differences (Table 2).

Standard metabolic rates of cuttlefish exposed acutely to $\sim 6000 \mathrm{ppm} \mathrm{CO}_{2}$ showed no significant increase or decrease over time $\left(F_{1,9}=2.9, \mathrm{p}>0.1\right.$; Fig. 3$)$. Mean oxygen consumption values during the control period were $0.092 \pm 0.004 \mu \mathrm{mol} \mathrm{O} \mathrm{g}^{-1} \mathrm{~min}^{-1}$, and after $24 \mathrm{~h}$ of $\mathrm{CO}_{2}$ exposure were $0.088 \pm 0.003 \mu \mathrm{mol} \mathrm{O} \mathrm{g}^{-1} \mathrm{~min}^{-1}$.

Growth of the calcified cuttlebone was determined both indirectly, from the mantle length of the cuttlefish, and directly, by measuring the amount of deposited $\mathrm{CaCO}_{3}$. At the end of the trial period, there

Table 2. Sepia officinalis. Growth and calcification during each of 2 separate trials under elevated $\mathrm{CO}_{2}$ conditions. Values are mean $\pm \mathrm{SD}, \mathrm{n}=20$ in each of the incubation groups

\begin{tabular}{|lcccccc|}
\hline $\begin{array}{l}\text { Incubation } \\
\text { group }\end{array}$ & $\begin{array}{c}\text { Initial } \\
\text { wet mass }(\mathrm{g})\end{array}$ & $\begin{array}{c}\text { Initial mantle } \\
\text { length }(\mathrm{mm})\end{array}$ & $\begin{array}{c}\text { Final } \\
\text { wet mass }(\mathrm{g})\end{array}$ & $\begin{array}{c}\text { Final mantle } \\
\text { length }(\mathrm{mm})\end{array}$ & $\begin{array}{c}\text { Daily } \\
\text { mass gain (\%) }\end{array}$ & $\begin{array}{c}\text { Gross growth } \\
\text { efficiency }(\%)\end{array}$ \\
\hline Control & $2.69 \pm 0.30$ & $20.53 \pm 0.14$ & $11.63 \pm 1.39$ & $37.16 \pm 1.88$ & 4.0 & $36.6 \pm 6.2$ \\
$\mathrm{CO}_{2} \sim 4000 \mathrm{ppm}$ & $2.70 \pm 0.33$ & $20.71 \pm 0.17$ & $11.16 \pm 1.40$ & $36.33 \pm 2.29$ & 3.8 & $38.9 \pm 3.6$ \\
$\mathrm{Control}$ & $4.61 \pm 1.01$ & $27.83 \pm 2.47$ & $24.15 \pm 5.25$ & $52.84 \pm 4.03$ & 3.9 & $39.5 \pm 4.5$ \\
$\mathrm{CO}_{2} \sim 6000 \mathrm{ppm}$ & $4.50 \pm 1.08$ & $27.90 \pm 2.39$ & $23.06 \pm 4.15$ & $52.01 \pm 4.76$ & 3.7 & $39.4 \pm 3.7$ \\
\hline
\end{tabular}


were no significant differences between the mantle lengths of control cuttlefish and those incubated at $\sim 6000 \mathrm{ppm} \mathrm{CO}_{2}(52.01 \pm 4.76 \mathrm{~mm}$ versus $52.84 \pm$ $4.03 \mathrm{~mm}$, respectively), nor between the control and $\sim 4000$ ppm $\mathrm{CO}_{2}$ incubated cuttlefish $(37.16 \pm 1.88 \mathrm{~mm}$

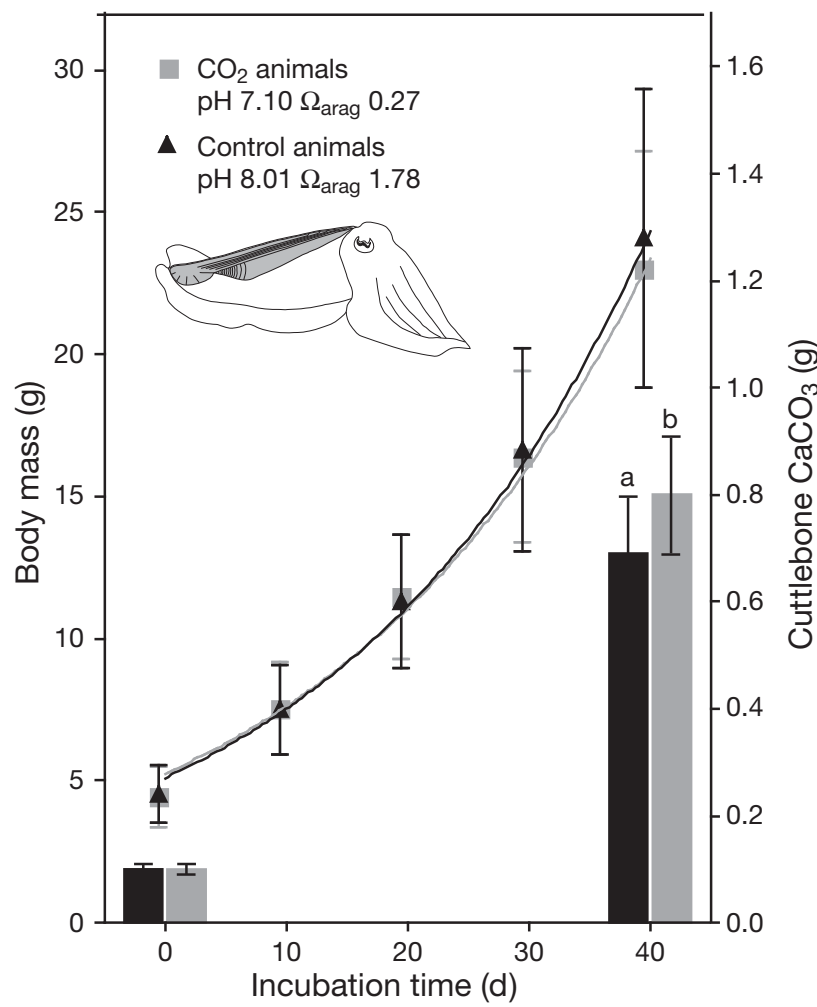

Fig. 2. Sepia officinalis. Growth ( $\square \mathbf{\Delta}$, left $y$-axis) and calcification (bars, right $y$-axis) in the cuttlefish incubated under $\sim 6000 \mathrm{ppm} \mathrm{CO}_{2}$ (grey) and control conditions (black). For $\mathrm{CaCO}_{3}$ accretion, means not sharing the same letter above bars are significantly different. Data are mean \pm SD $(n=20)$. The calcified cuttlebone is shaded grey in the schematic drawing of $S$. officinalis

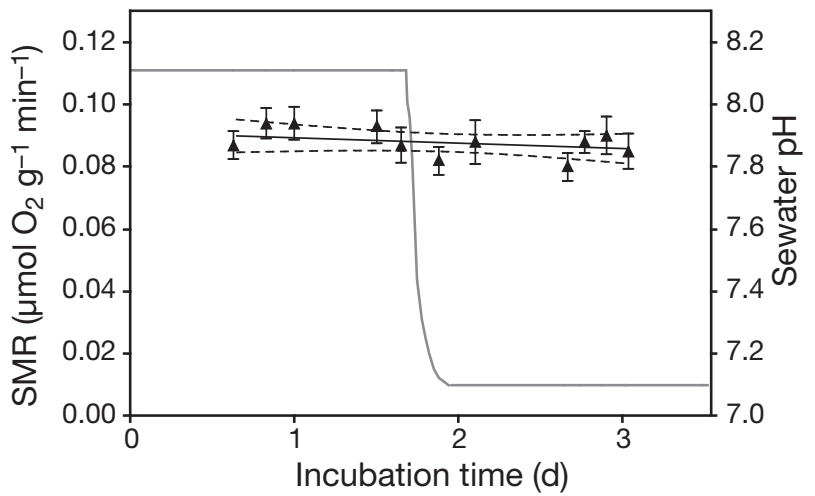

Fig. 3. Sepia officinalis. Standard metabolic rate (SMR) of cuttlefish during acute exposure to $\sim 6000 \mathrm{ppm} \mathrm{CO}_{2}$ (४). Cuttlefish were placed in the chambers at Time $=0$ and $\mathrm{CO}_{2}$ exposure was started after $40 \mathrm{~h}$ of control measurements; the change in seawater $\mathrm{pH}$ (grey curve) reflects the time course of $\mathrm{CO}_{2}$ exposure. Data are mean $\pm \mathrm{SD}, \mathrm{n}=6$ versus $36.33 \pm 2.29 \mathrm{~mm}$, respectively) (Table 2 ). During the 6 wk growth period all of the cuttlefish increased the mass of their cuttlebones by over $500 \%$ (Fig. 3). Interestingly, in the $\sim 6000 \mathrm{ppm} \mathrm{CO}_{2}$ growth trial, the $\mathrm{CO}_{2}$ incubated animals incorporated significantly more $\mathrm{CaCO}_{3}$ into their cuttlebones than did the control group, $0.80 \pm 0.15 \mathrm{~g}$ versus $0.71 \pm 0.15 \mathrm{~g}$, respectively. Functional control of the cuttlebones (i.e. buoyancy regulation) did not appear to be negatively affected by low $\mathrm{pH}$ conditions.

\section{DISCUSSION}

The results of our growth trial show that at least 1 marine invertebrate species is capable of maintaining both metabolic rates and somatic growth performance at control levels during long-term exposure to significantly elevated seawater $\mathrm{CO}_{2}$ concentrations.

\section{Growth}

Sepia officinalis juveniles cultured at $\sim 4000$ and $\sim 6000$ ppm $\mathrm{CO}_{2}$ grew at the same rate as did control individuals, gaining body mass at a rate of approximately $4 \%$ body mass $\mathrm{d}^{-1}$ (Table 2 ). These growth rates closely correspond with results from previous work, where $S$. officinalis of similar size gained 3.5\% body mass $\mathrm{d}^{-1}$ at $17^{\circ} \mathrm{C}$ (Forsythe et al. 2002). Under both $\mathrm{CO}_{2}$ conditions, there was no significant difference between control and treatment final wet mass gained during the 6 wk growth intervals. All cuttlefish more than quadrupled their body mass (Table 2). These results are in stark contrast to existing invertebrate growth studies under elevated $\mathrm{CO}_{2}$. Michaelidis et al. (2005) found that under comparable $\mathrm{CO}_{2}$ levels to our study, and over a growth period of $3 \mathrm{mo}$, shell length and soft body mass in the mussel Mytilus galloprovincialis were reduced by 55 and $70 \%$, respectively (as calculated from their Fig. 3). Even more striking is the study reported by Shirayama \& Thornton (2005) where significant differences in total body mass were measured in the sea urchin Echinometra mathaei and the gastropod Strombus luhuanus incubated under just 560 ppm $\mathrm{CO}_{2}$ for half a year. Clearly, $S$. officinalis does not exhibit sensitivity to elevated $\mathrm{CO}_{2}$ levels within the range of concentrations that elicits a negative response in most other invertebrates studied to date.

\section{Metabolism}

Reduced growth performance in marine invertebrates under elevated $\mathrm{CO}_{2}$ conditions has been suggested to 
be a result of the organisms entering a state of metabolic depression (Pörtner et al. 2004). The cellular processes mediating metabolic depression have been extensively reviewed (Hand \& Hardewig 1996, Guppy \& Withers 1999, Storey \& Storey 2007), and hypercapnia alone as an environmental stressor has been found to induce metabolic depression (Barnhart 1989, Rees \& Hand 1990). Recent case studies on marine invertebrates support this conclusion; in Sipunculus nudus (Pörtner et al. 1998) and Mytilus galloprovincialis (Michaelidis et al. 2005) a decrease in metabolic rate in response to both acute and long-term hypercapnia exposure was accompanied by an uncompensated decrease in extracellular $\mathrm{pH}\left(\mathrm{pH}_{\mathrm{e}}\right)$. Working with an isolated muscle model, Pörtner et al. (2000) suggested that decreasing $\mathrm{pH}_{\mathrm{e}}$ slows down the rate of $\mathrm{H}^{+}$equivalent ion exchange between the extra- and intracellular space, and this in turn reduces the work load of $\mathrm{Na}^{+} / \mathrm{K}^{+}$-ATPase in maintaining the transepithelial electrochemical gradient. With this arrangement, organisms could effectively lower the energy requirements of acid-base regulation in their cells. However, they would still face new steady-state levels of decreased extracellular $\mathrm{pH}$, elevated $\mathrm{pCO}_{2}$ and $\mathrm{HCO}_{3}{ }^{-}$, which might have long-term effects on metabolic function (Reipschläger \& Pörtner 1996). These could include changes in amino acid catabolism, with a preference towards net formation of metabolic bicarbonate for buffering (Langenbuch \& Pörtner 2002). In combination with reduced rates of protein biosynthesis under low pH conditions (Smith et al. 1996, Reid et al. 1997, Langenbuch \& Pörtner 2003), such processes would eventually limit somatic growth.

Metabolic depression is not evident in Sepia officinalis in response to acute $\mathrm{CO}_{2}$ exposure, which matches the conserved growth rates observed in our study. Standard metabolic rates of around $0.09 \mu \mathrm{mol} \mathrm{O}_{2} \mathrm{~g}^{-1}$ $\min ^{-1}$ were maintained at a constant level during acute exposure to $\sim 6000 \mathrm{ppm} \mathrm{CO}_{2}$ (Fig. 2). The control metabolic rates we measured in $S$. officinalis match previously published values for similarly sized animals (Melzner et al. 2007a). A recent study working with the brittle star Amphiura filiformis also found no evidence of metabolic depression during long-term hypercapnic exposure under similar $\mathrm{CO}_{2}$ levels (Wood et al. 2008). In fact, a significant increase in metabolic rate was found along with dramatic arm muscle wastage at an incubation pH of 7.3 (Wood et al. 2008). The catabolism of arm muscle to support elevated metabolic costs during hypercapnia, however, is indicative of a restructuring of the energy budget that significantly compromises long-term animal fitness.

In contrast, the cuttlefish in this study were not only capable of conserving growth and metabolic rates, but they also maintained their GGE at control levels under both $\sim 4000$ and $\sim 6000 \mathrm{ppm} \mathrm{CO}_{2}$ (Table 1). This suggests that the partitioning of their energy budget was conserved under hypercapnia, and that they did not simply ingest more food to maintain growth performance. Our GGE values, ranging from 36 to $39 \%$, correspond with published values of 30 to $50 \%$ (Forsythe et al. 2002) for Sepia officinalis cultured at $17^{\circ} \mathrm{C}$. A similar response is also known in fish, where metabolic rates and growth are not influenced even by high degrees of hypercapnia. Working with juvenile spotted wolffish Anarhichas minor, Foss et al. (2003) reported conserved growth rates, as well as food conversion efficiencies, at $\mathrm{CO}_{2}$ concentrations up to $17000 \mathrm{ppm}$ $\mathrm{CO}_{2}$. Fish are capable of maintaining growth rates under elevated $\mathrm{CO}_{2}$ conditions because of their high ion transport and acid-base regulatory abilities. During acute hypercapnic exposure they rapidly increase $\mathrm{HCO}_{3}{ }^{-}$levels in their blood, and are able to fully compensate their extracellular pH (Toews et al. 1983, Claiborne \& Evans 1992, Larsen et al. 1997, Hayashi et al. 2004, Michaelidis et al. 2007). Thus, in contrast to most invertebrates, $\mathrm{pH}_{\mathrm{e}}$ is not depressed in fish during moderate, long-term hypercapnic exposure and, thus, does not influence potential reductions in metabolism and growth. The elevation of $\mathrm{HCO}_{3}{ }^{-}$levels in response to hypercapnia-induced acidification is a response common to most organisms (Heisler 1989); however, the degree to which $\mathrm{pH}$ is compensated is dependent on ion-regulatory capacity and is species specific.

\section{Calcification}

Not only does Sepia officinalis successfully acquire soft tissue mass under elevated $\mathrm{CO}_{2}$ conditions, but it also maintains high calcification rates of its cuttlebone. $S$. officinalis is capable of calcifying under $\sim 6000 \mathrm{ppm}$ $\mathrm{CO}_{2}$ and $\Omega_{\text {arag }}$ values of 0.27 . Cuttlebone formation rate, as determined from mantle length measurements, was equal between all of the growth trial groups (Table 2). The cuttlebone is a fully internalized shell that is encased in a cuttlebone sac (Appellöf 1893), dorsally positioned along the anterior-posterior plane (see Fig. 3). When directly measured, total calcium carbonate accumulation in the cuttlebones of the $\sim 6000$ ppm $\mathrm{CO}_{2}$ incubated individuals was actually found to be significantly higher than in the control group (Fig. 3 ). This puts $S$. officinalis in a unique position in relation to existing studies, since most invertebrates examined to date exhibit a negative influence of elevated $\mathrm{CO}_{2}$ concentrations on calcification, and in some organisms there is a linear decrease of calcification rate with decreasing $\Omega_{\text {arag }}$ (Fig. 1). As far as we are aware, only one other study working with long-term hypercapnic exposure in invertebrates has shown in- 
creased calcification rates under elevated seawater $\mathrm{CO}_{2}$ levels (Wood et al. 2008).

Considering that calcification requires tight control of ionic composition and $\mathrm{pH}$ in the micro-environment at the deposition site (Weiner \& Dove 2003), it seems likely that Mytilus galloprovincialis, and other invertebrates with low metabolic rates or low ion exchange capacities, are not capable of maintaining conditions favorable to mineral deposition under the acidification stress of hypercapnia. Findings of elevated calcium ions $\left(\mathrm{Ca}^{2+}\right)$ in $M$. galloprovincialis hemolymph, in combination with the previously mentioned uncompensated $\mathrm{pH}_{\mathrm{e}}$ reduction (Michaelidis et al. 2005), support such a hypothesis. In contrast, calcification at $\Omega_{\text {arag }}<1$ in Sepia officinalis could be directly related to high, 'fish-like', ion regulatory capacities in this active invertebrate.

\section{SUMMARY}

We conclude that marine ectothermic organisms with high metabolic rates (teleost fish, cephalopods) might be characterised by a certain level of pre-adaptation to acidification enabling them to grow and calcify under long-term elevated $\mathrm{CO}_{2}$ conditions. By means of competition for similar resources, both fish and cephalopods have been forced into an active, highpower style of living (e.g. O'Dor \& Webber 1986, 1991). During exercise, cephalopods are known to encounter $\mathrm{CO}_{2}$ partial pressures $>3000$ ppm in their blood (Pörtner et al. 1991), which are values that are twice as high as those predicted for the world's oceans for the year 2300 (Caldeira \& Wickett 2003). However, they are known to protect their blood from exercise-induced acidification by recycling octopine and associated protons in their mantle tissue (Pörtner et al. 1993). Since a stable blood $\mathrm{pH}$ is necessary for the proper function of their extracellular oxygen pigment hemocyanin (e.g. Melzner et al. 2007b), active cephalopods must possess a sophisticated ion transport machinery (and appropriate buffering systems) to cope with high, exerciseinduced, $\mathrm{CO}_{2}$ concentrations on a daily basis. Ongoing work on the blood acid-base parameters and the general ion regulatory ability of Sepia officinalis in response to hypercapnia will provide further insights.

Our work underlines the importance of improving our understanding of the processes responsible for biocalcification, growth and physiological homeostasis, when aiming towards predicting sensitivities of marine invertebrates to future climate change. The cuttlefish Sepia officinalis might, therein, serve as an important invertebrate model organism to identify specific biological mechanisms that promote tolerance to long-term reductions in seawater $\mathrm{pH}$ and calcium carbonate saturation.
Acknowledgements. We thank M. P. and R. Chichery, Université de Caen, France, and A. Wittmann for providing Sepia officinalis eggs. We also extend our thanks to J. Pungor and P. Santelices for help with the growth trials. We are grateful for the suggestions of 3 anonymous reviewers that improved the manuscript. This study was supported by DAAD (M.A.G.), the AWI MARCOPOLI Program (M.A.G., H.O.P., F.M.) and the DFG Excellence Cluster 'Future Ocean' (F.M.). This work is a contribution to the European Project on Ocean Acidification (EPOCA), which received funding from the European Community's Seventh Framework Programme (FP7/20072013) under grant agreement no. 211384.

\section{LITERATURE CITED}

Appellöf A (1893) Die Schalen von Sepia, Spirula, and Nautilus. Studien über den Bau und das Wachstum. Kongl Svenska Vetenskaps-Akademiens Handlingar 25:1-106

Barnhart MC (1989) Respiratory acidosis and metabolic depression in dormant invertebrates. In: Malan A, Canguilhem B (eds) Living in the cold. Colloque INSERM/ John Libbey Eurotext, London, p 315-401

Birchall JD, Thomas NL (1983) On the architecture and function of cuttlefish bone. J Mater Sci 18:2081-2086

Caldeira K, Wickett ME (2003) Anthropogenic carbon and ocean $\mathrm{pH}$. Nature 425:365

Claiborne JB, Evans DE (1992) Acid-base balance and ion transfers in the spiny dogfish (Squalus acanthias) during hypercapnia: a role for ammonia excretion. J Exp Zool 261:9-17

Denton EJ, Gilpin-Brown JB (1961a) The buoyancy of the cuttlefish Sepia officinalis. J Mar Biol Assoc UK 41:319-342

Denton EJ, Gilpin-Brown JB (1961b) The effect of light on the buoyancy of the cuttlefish. J Mar Biol Assoc UK 41: 343-350

- Dickson AG, Millero FJ (1987) A comparison of the equilibrium constants for the dissociation of carbonic acid in seawater media. Deep-Sea Res 34:1733-1743

Fabry VJ, Seibel BA, Feely RA, Orr JC (2008) Impacts of ocean acidification on marine fauna and ecosystem processes. ICES J Mar Sci 65:414-432

Feely RA, Sabine CL, Lee K, Berelson W, Kleypas J, Fabry VJ, Millero FJ (2004) Impact of anthropogenic $\mathrm{CO}_{2}$ on the $\mathrm{CaCO}_{3}$ system in the oceans. Science 305:362-366

Forsythe J, DeRusha RH, Hanlon RT (1994) Growth, reproduction and life span of Sepia officinalis (Cephalopoda: Mollusca) cultured through seven consecutive generations. J Zool 233:175-192

Forsythe J, Lee P, Walsh L, Clark T (2002) The effects of crowding on growth of the European cuttlefish, Sepia officinalis Linnaeus, 1758 reared at two temperatures. J Exp Mar Biol Ecol 269:173-185

Foss A, Rønes BA, Øiestad V (2003) Graded environmental hypercapnia in juvenile spotted wolffish (Anarhichas minor Olafsen): effects on growth, food conversion efficiency and nephrocalcinosis. Aquaculture 220:607-617

Gazeau F, Quibler C, Jansen JM, Gattuso JP, Middelburg JJ, Heip CHR (2007) Impact of elevated $\mathrm{CO}_{2}$ on shellfish calcification. Geophys Res Lett 34, L07603, doi:10.1029/2006 GL028554

Guppy M, Withers P (1999) Metabolic depression in animals: physiological perspectives and biochemical generalizations. Biol Rev 74:1-40

Hand SC, Hardewig I (1996) Downregulation of cellular metabolism during environmental stress: mechanisms and implications. Annu Rev Physiol 58:539-563 
Hayashi M, Kita J, Ishimatsu A (2004) Acid-base responses to lethal aquatic hypercapnia in three marine fish. Mar Biol 144:153-160

Heisler N (1989) Interactions between gas exchange, metabolism, and ion transport in animals: an overview. Can J Zool 67:2923-2935

Langdon C, Takahashi T, Sweeney C, Chipman D and others (2000) Effect of calcium carbonate saturation state on the calcification rate of an experimental coral reef. Global Biogeochem Cycles 14:639-654

> Langenbuch M, Pörtner HO (2002) Changes in metabolic rate and $\mathrm{N}$ excretion in the marine invertebrate Sipunculus nudus under conditions of environmental hypercapnia: identifying effective acid-base variables. J Exp Biol 205: 1153-1160

> Langenbuch M, Pörtner HO (2003) Energy budget of hepatocytes from Antarctic fish (Pachycara brachycephalum and Lepidonotothen kempi) as a function of ambient $\mathrm{CO}_{2}$ : $\mathrm{pH}$ dependent limitations of cellular protein biosynthesis? J Exp Biol 206:3895-3903

> Larsen BK, Pörtner HO, Jensen FB (1997) Extra- and intracellular acid-base balance and ionic regulation in cod (Gadus morhua) during combined and isolated exposures to hypercapnia and copper. Mar Biol 128:337-346

Lenfant C, Aucutt C (1966) Measurement of blood gases by gas chromatography. Respir Physiol 1:398-407

Lewis E, Wallace DWR (1998) Program developed for $\mathrm{CO}_{2}$ system calculations. ORNL/CDIAC-105, Carbon Dioxide Information Analysis Center, Oak Ridge National Laboratory, Oak Ridge, TN. Available at: cdiac.esd.ornl.gov/ oceans/co2rprt.html

Mehrbach C, Culberson CH, Hawley JE, Pytkowicz RM (1973) Measurement of the apparent dissociation constants of carbonic acid in seawater at atmospheric pressure. Limnol Oceanogr 18:897-907

Melzner F, Forsythe JW, Lee PG, Wood JB, Piatkowki U, Clemmesen C (2005) Estimating recent growth in the cuttlefish Sepia officinalis: Are nucleic acid based indicators for growth and condition the method of choice? J Exp Mar Biol Ecol 317:37-51

Melzner F, Bock C, Pörtner HO (2007a) Allometry of thermal limitation in the cephalopod Sepia officinalis. Comp Biochem Physiol A Mol Intergr Physiol 146:149-154

Melzner F, Mark FC, Pörtner HO (2007b) Role of bloodoxygen transport in thermal tolerance of the cuttlefish, Sepia officinalis. Integr Comp Biol 47:645-655

Michaelidis B, Ouzounis C, Paleras A, Pörtner HO (2005) Effects of long-term moderate hypercapnia on acid-base balance and growth in marine mussels Mytilus galloprovincialis. Mar Ecol Prog Ser 293:109-118

Michaelidis B, Spring A, Pörtner HO (2007) Effects of longterm acclimation to environmental hypercapnia on extracellular acid-base status and metabolic capacity in the Mediterranean fish Sparus aurata. Mar Biol 150:1417-1429

O'Dor RK, Webber DM (1986) The constraints on cephalopods: Why squid aren't fish. Can J Zool 64:1591-1605

O'Dor RK, Webber DM (1991) Invertebrate athletes: tradeoffs between transport efficiency and power density in cephalopod density. J Exp Biol 160:93-112

Orr JC, Fabry VJ, Aumont O, Bopp L and others (2005) Anthropogenic ocean acidification over the twenty-first century and its impact on calcifying organisms. Nature 437:681-686

Pörtner HO, Boutilier RG, Tang Y, Toews DP (1990) Determination of intracellular $\mathrm{pH}$ and $\mathrm{pCO}_{2}$ after metabolic inhibition by fluoride and nitrilotriacetic acid. Respir Physiol 81:255-274

Pörtner HO, Webber DM, Boutilier RG, O'Dor RK (1991) Acid-base regulation in exercising squid (Illex illecebrosus, Loligo pealei). Am J Physiol 261:239-246

Pörtner HO, Webber DM, O'Dor RK, Boutilier RG (1993) Metabolism and energetics in squid (Illex illecebrosus, Loligo pealei) during muscular fatigue and recovery. Am J Physiol 265:157-165

> Pörtner HO, Reipschläger A, Heisler N (1998) Acid-base regulation, metabolism and energetics in Sipunculus nudus as a function of ambient carbon dioxide level. J Exp Biol 201:43-64

> Pörtner HO, Bock C, Reipschläger A (2000) Modulation of the cost of pHi regulation during metabolic depression: a ${ }^{31} \mathrm{P}-$ NMR study in invertebrate (Sipunculus nudus) isolated muscle. J Exp Biol 203:2417-2428

Pörtner HO, Langenbuch M, Reipschläger A (2004) Biological impact of elevated ocean $\mathrm{CO}_{2}$ concentration: lessons from animal physiology and Earth history. J Oceanogr 60: $705-718$

Rees BB, Hand SC (1990) Heat dissipation, gas exchange and acid-base status in the land snail Oreohelix during shortterm estivation. J Exp Biol 152:77-92

> Reid SD, Dockray JJ, Linton TK, McDonald DG, Wood CM (1997) Effects of chronic environmental acidification and summer global warming scenario: protein synthesis in juvenile rainbow trout (Oncorhynchus mykiss). Can J Fish Aquat Sci 54:2014-2024

Reipschläger A, Pörtner HO (1996) Metabolic depression during environmental stress: the role of extra- versus intra-cellular $\mathrm{pH}$ in Sipunculus nudus. J Exp Biol 199: 1801-1807

Seibel BA, Walsh PJ (2003) Biological impacts of deep-sea carbon dioxide injection inferred from indices of physiological performance. J Exp Biol 206:641-650

Shirayama Y, Thornton H (2005) Effects of increased atmospheric $\mathrm{CO}_{2}$ on shallow water marine benthos. J Geophys Res 110, C09S08, doi:10.1029/2004JC002618

Smith RW, Houlihan DF, Nilsson GE, Brechin JG (1996) Tissuespecific changes in protein synthesis rates in vivo during anoxia in crucian carp. Am J Physiol Regul Integr Comp Physiol 271:R897-R904

> Storey KB, Storey JM (2007) Tribute to P. L. Lutz: putting life on 'pause'-molecular regulation of hypometabolism. J Exp Biol 210:1700-1714

Toews DP, Holeton GF, Heisler N (1983) Regulation of the acid-base status during environmental hypercapnia in the marine teleost fish Conger conger. J Exp Biol 107:9-20

- Weiner S, Dove PM (2003) An overview of biomineralization processes and the problem of the vital effect. Rev Mineral Geochem 54:1-29

> Wood HL, Spicer JI, Widdicombe S (2008) Ocean acidification may increase calcification rates, but at a cost. Proc R Soc B Biol Sci 275:1767-1773

Zeebe RE, Wolf-Gladrow DA (2001) $\mathrm{CO}_{2}$ in seawater: equilibrium, kinetics, isotopes. Elsevier, Amsterdam 